\title{
Metamorphic evolution of the contact aureole of the Jhirgadandi pluton, Sonbhadra district, Mahakoshal mobile belt, central India
}

\author{
S P Singh ${ }^{1, *}$, Anand K Srivastava ${ }^{2}$, Gopendra Kumar ${ }^{3}$ and S B Dwivedi ${ }^{4}$ \\ ${ }^{1}$ Department of Geology, Institute of Earth Science, Bundelkhand University, Jhansi 284 128, India. \\ ${ }^{2}$ Formerly, Department of Geology, Lucknow University, 124 Kashipur House, Aryanagar, \\ Lucknow 226 004, India. \\ ${ }^{3}$ Formerly, Geological Survey of India, B58, Kendriya Vihar Apartment, Sector 6, Jankipuram Vistar, \\ Lucknow 226 021, India. \\ ${ }^{4}$ Department of Civil Engineering, Indian Institute of Technology (BHU), Varanasi 221 005, India. \\ ${ }^{*}$ Corresponding author. e-mail: spsinghbu@rediffmail.com
}

The metamorphic evolution of the contact aureole around the Late Paleoproterozoic Jhirgadandi pluton in the eastern part of Parsoi Formation of Mahakoshal terrain, central India represents three distinct metamorphic zones, characterized by definite mineral assemblages. The contact-metamorphic event produced the peak-metamorphic mineral assemblages Bt $+\mathrm{Qtz}+\mathrm{Alb}+\mathrm{Sil} \pm \mathrm{Cd} \pm \mathrm{Grt} \pm \mathrm{Mus} \pm \mathrm{Kfs}$ in the metapelites of inner aureole, Bt $+\mathrm{Qtz}+\mathrm{And}+\mathrm{Mus}+\mathrm{Kfs}+\mathrm{Plag} \pm \mathrm{Cd} \pm \mathrm{Chl}$ in middle aureole and $\mathrm{Chl}+\mathrm{Mus}+\mathrm{Bt} \pm \mathrm{And}+\mathrm{Alb}+\mathrm{Qtz} \pm \mathrm{Ep}+\mathrm{Mt} \pm$ tourmaline in the outer aureole. The estimated $\mathrm{P}-\mathrm{T}$ conditions based on detailed geothermobarometric calculations in the thermal metamorphosed rocks are $690^{\circ} \mathrm{C} / 3.4 \mathrm{kbar}, 580 \pm 15^{\circ} \mathrm{C}$ and $487 \pm 30^{\circ} \mathrm{C}$ in inner aureole, middle aureole and outer aureole, respectively. The variation in metamorphic condition suggests that the shallow crustal level emplacement of Jhirgadandi pluton is responsible for the overprinting of contact metamorphic assemblages $\left(\mathrm{M}_{2}\right)$ in the low grade metapelites (regional metamorphism $\mathrm{M}_{1}$ ) of Mahakoshal Group.

\section{Introduction}

The emplacement of granitic pluton at shallow depth forms a thermal aureole which is associated with textural, chemical and mineralogical changes in wall rock. Such mineralogical and textural transformations are functions of a distance from the contact with the pluton, chemical composition of the country rock, temperature of the intruding magma, composition of coexisting fluid phases and permeability of the wall rock (Norton and Knight 1977; Hanson 1995; Cartwright and Buick 1996; Brocker and Franz 2000; Kusunose et al. 2003; Rossetti et al. 2007). The occurrences of well-developed contact aureoles and their systematic petrological studies have been reported from several localities (Kerrick 1987; Buntebarth 1991; Symmes and Ferry 1995; Kusunose et al. 2003; Brocker and Franz 2000; Buriánek and Dolníček 2011), which lead to better understanding the processes with respect to space and time. Although few studies on thermal aureoles in Paleozoic granitoids of the Himalayan fold belt, particularly from the Tethys zone (Thakur 1993; Pognante et al. 1990; Steck et al. 1998; Vijan et al. 2003) and from the Lesser Himalaya of Kumaun region (Das 1985) have been

Keywords. Contact aureole; geothermobarometry; hornfels texture; Jhirgadandi pluton; superimposed metamorphism. 
carried out, contact aureoles from the peninsular part of Indian subcontinents are relatively least studied. A number of granitic intrusions associated with contact metamorphism have also been reported from the Mahakoshal belt of central India (Srivastava 1969; Nair et al. 1995; Roy et al. 2002; Kumar 2005) however, none of the works brought details on thermal aureoles and systematic documentation of their geothermobarometry. Through detailed petrographic, mineral chemistry and $\mathrm{P}-\mathrm{T}$ conditions, we try to fill this gap by providing new constraints on the metamorphic evolution of the thermal aureole of Jhirgadandi pluton in the eastern part of the Mahakoshal Belt.

\section{Geological setting}

The arc-shaped supracrustal belt constituting the Mahakoshal Group (Nair et al. 1995), earlier known as Bijawar Group (Mathur and Narain 1981; Iqballudin and Mohgni 1981), is developed along the southern margin of Bundelkhand Craton. The 'Mahakoshal Group' represents a rift basin developed during the Paleoproterozoic in central India (Srivastava et al. 2000a, b; Roy 2008). The belt is about $500 \mathrm{~km}$ in length and extends from northeast corner of Jabalpur district of Madhya Pradesh along the Son Valley to the border of Palamau, in Jharkhand (figure 1). This belt forms the northern part of the Central Indian Tectonic Zone (CITZ) (Radhakrishna 1989; Acharyya and Roy 2000) and constitutes a part of Son Narmada (SONATA) zone (Ravi Shanker 1993). The
Mahakoshal Group constitutes volcanosedimentary rock sequences of Paleoproterozoic and developed between the Bundelkhand Craton in the north and Chhotanagpur Gneissic Complex of peninsular Indian shield in the south. According to Nair et al. (1995) and Srivastava et al. (2000a), the Mahakoshal Group comprises of Chitrangi, Agori and Parsoi Formations in ascending order. Subsequently, Kumar (2005) separated out Parsoi Formation from the Mahakoshal Group on the basis of record of polymictic conglomerate (Roy and Devarajan 2000) at its base and considered the Chitrangi and Agori Formations to be part of the Mahakoshal Group of Archaean age. The northern boundary of Mahakoshal belt has sheared relationship with the granite-gneisses of Sidhi block and as faulted contact and at some places angular unconformable contact with the Vindhyan Supergroup (figure 1). The southern part of Mahakoshal Group also has a sheared relationship with granite gneisses of Chhotanagpur block. The Parsoi Formation comprises low grade pelitic metasediments, bluish grey or green in colour with silky lusture with banded or ribbon-like structures, and sometimes with varve-like alternating light and dark gray bands. The arenaceous sediments occur as lenticles and laminae in the main phyllitic mass (Srivastava 1969).

The present study area forms a part of the eastern extremity of the Parsoi Formation of Mahakoshal belt. The Jhirgadandi pluton is lensoidal in shape, trending in the $\mathrm{E}-\mathrm{W}$ direction with an area extension of ca $20 \mathrm{~km}^{2}$. It is exposed near the confluence of Kanhar River with Son River

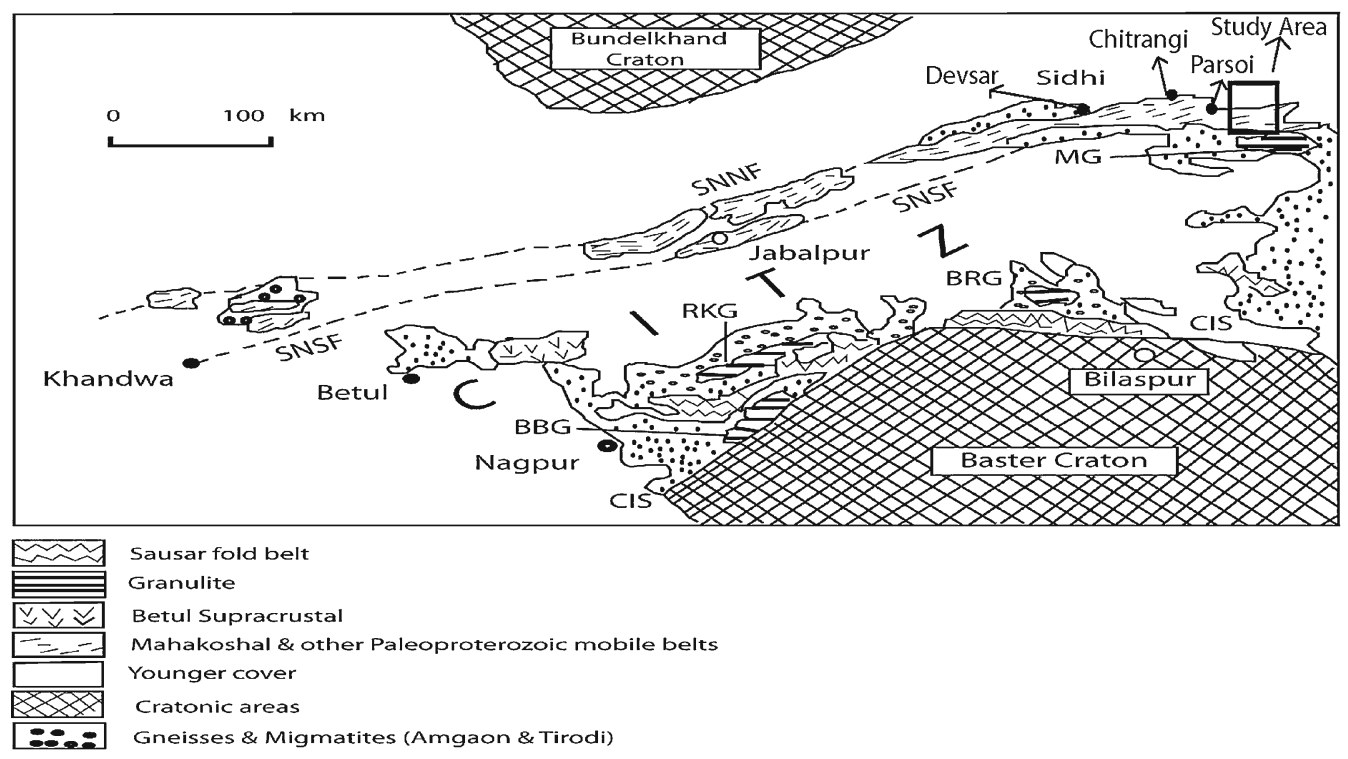

Figure 1. Regional geological map showing the arch shaped Mahakoshal Group bounded between Son-Narmada south fault (SNFS) and Son-Narmada north fault (SNNF). The abbreviations are: CITZ=Central Indian Tectonic Zone, CIS=Central Indian Suture (after Roy et al. 2002). 
(figure 2a). The thermal aureole has been studied in the southern part only whereas its northern part is faulted by north Son-Narmada Fault (Srivastava 1969). The Jhirgadandi aureole has average uniform width of $600 \mathrm{~m}$ and the main part of aureole is situated between the villages Parach and Nigai where it has maximum width ca $800 \mathrm{~m}$ (figure $2 \mathrm{~b}$ ).
The granitoid of Jhirgadandi is interpreted to be hybrid type post-orogenic granitoid, highly metaluminous, transitional between sub-alkaline and calcalkaline with low initial Sr ratios (Nair et al. 1995; Srivastava et al. 2000a; Roy 2008; Srivastava and Kumar 2010). Based on the model composition, it is suggested to be composite in character, having

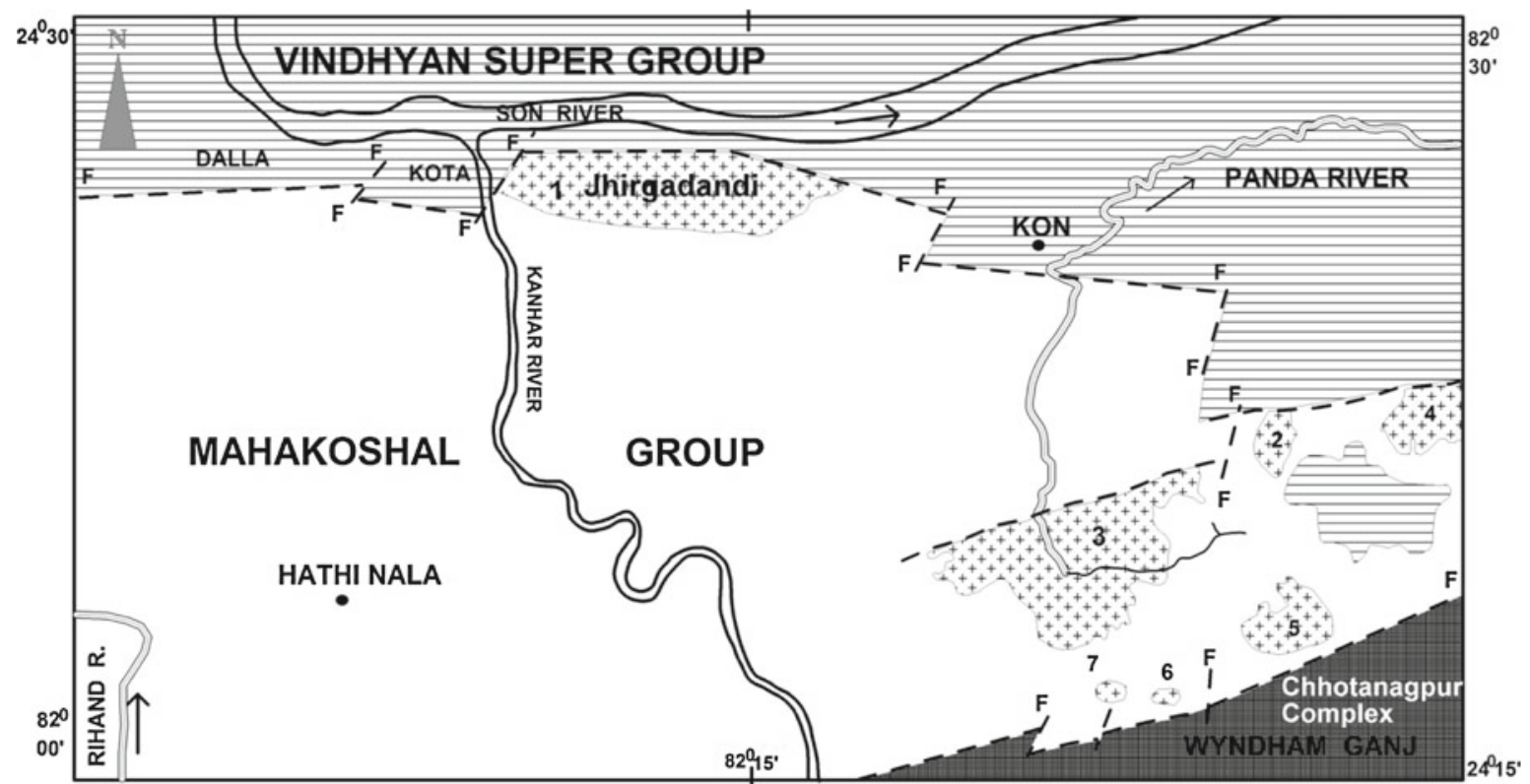

(a)

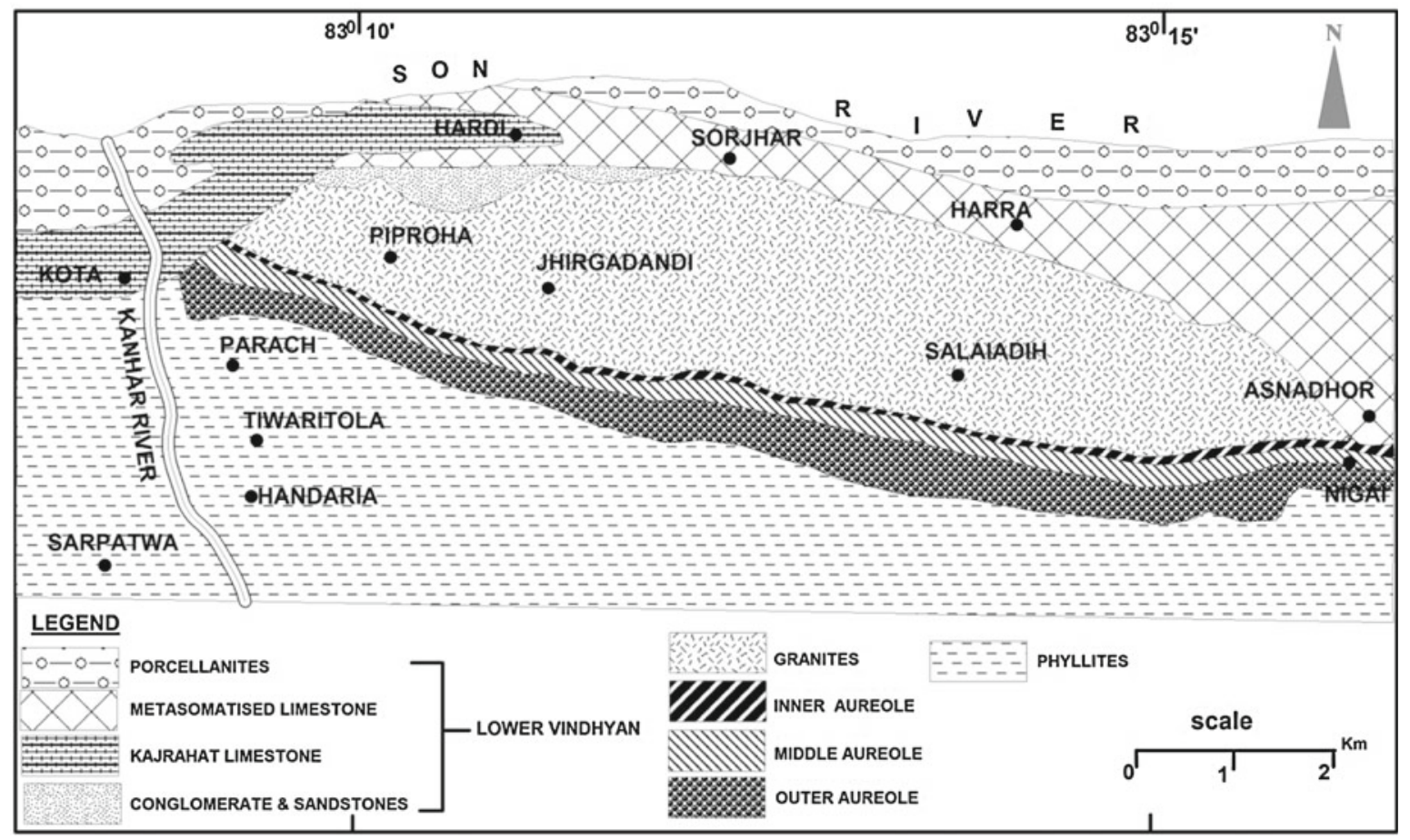

(b)

Figure 2. (a) Geological map of the eastern part of Parsoi Formation of Mahakoshal Group showing series of granitoid intrusives, marked by numbers. $1=$ Jhirgadandi, $2=$ Baghisoti, $3=$ Tumia, $4=$ Rohiniyan, $5=$ Kumba Khurd, $6=$ Harnakachar (Kon road) and $7=$ Harnakachar. (b) Geological map around Jhirgadandi showing the three zones of contact aureole at the southern part of Jhirgadandi pluton (modified after Srivastava 1977). 
a granodioritic core fringed by quartz-monzonite, with gradational contact (Srivastava 1977). The less precise $\mathrm{Rb}-\mathrm{Sr}$ whole rock radiometric ages $(1869 \pm 180$ and $1813 \pm 65 \mathrm{Ma}$, Pande et al. 1996; Sarkar et al. 1998) and $1753 \pm 9 \mathrm{U}-\mathrm{Pb}$ zircon SHRIMP geochronological data (Sita Bora and Kumar 2012) indicate a predominant Late Paleoproterozoic intrusion event for the Jhirgadandi pluton.

\section{Architecture of the Jhirgadandi aureole}

The thermal aureole of the Jhirgadandi pluton is about $600 \mathrm{~m}$ wide (figure 3a). The metamorphic rocks in the aureole are mainly metapelites with layers of metapsammites of several $\mathrm{mm}$ to $\mathrm{cm}$ thickness. Based on the textural and mineralogical associations the aureole has been divided into three parts, viz., inner, middle and outer aureoles/zones. Relics of sedimentary textures are nearly absent in the inner aureole and occasionally preserved in the middle and frequently observed in outer aureole.

\subsection{Country rocks outside the contact aureole}

In general, the Parsoi Formation is characterized by low-grade tuffaceous phyllite and metasediments of green-schist facies, occupying the large area between Jhirgadandi to Renukoot of Son valley (Nair et al. 1995; Roy et al. 2002). Metasediments contain white mica (sericite), chlorite, quartz, albite and sometimes graphite. A metamorphic mineral association of metavolcanics consists chlorite + actinolite + albite + epidote \pm quartz \pm white mica \pm prehnite \pm calcite \pm biotite \pm titanite \pm ilmenite \pm magnetite (Nair et al. 1995). Some times the chlorite porphyroblasts (up to $0.9 \mathrm{~mm}$ across) are arranged parallel or subparallel to the axial planes of crenulation folds developed which is defined by the mineral assemblage actinolite+epidote +feldspar +quartz+chlorite.
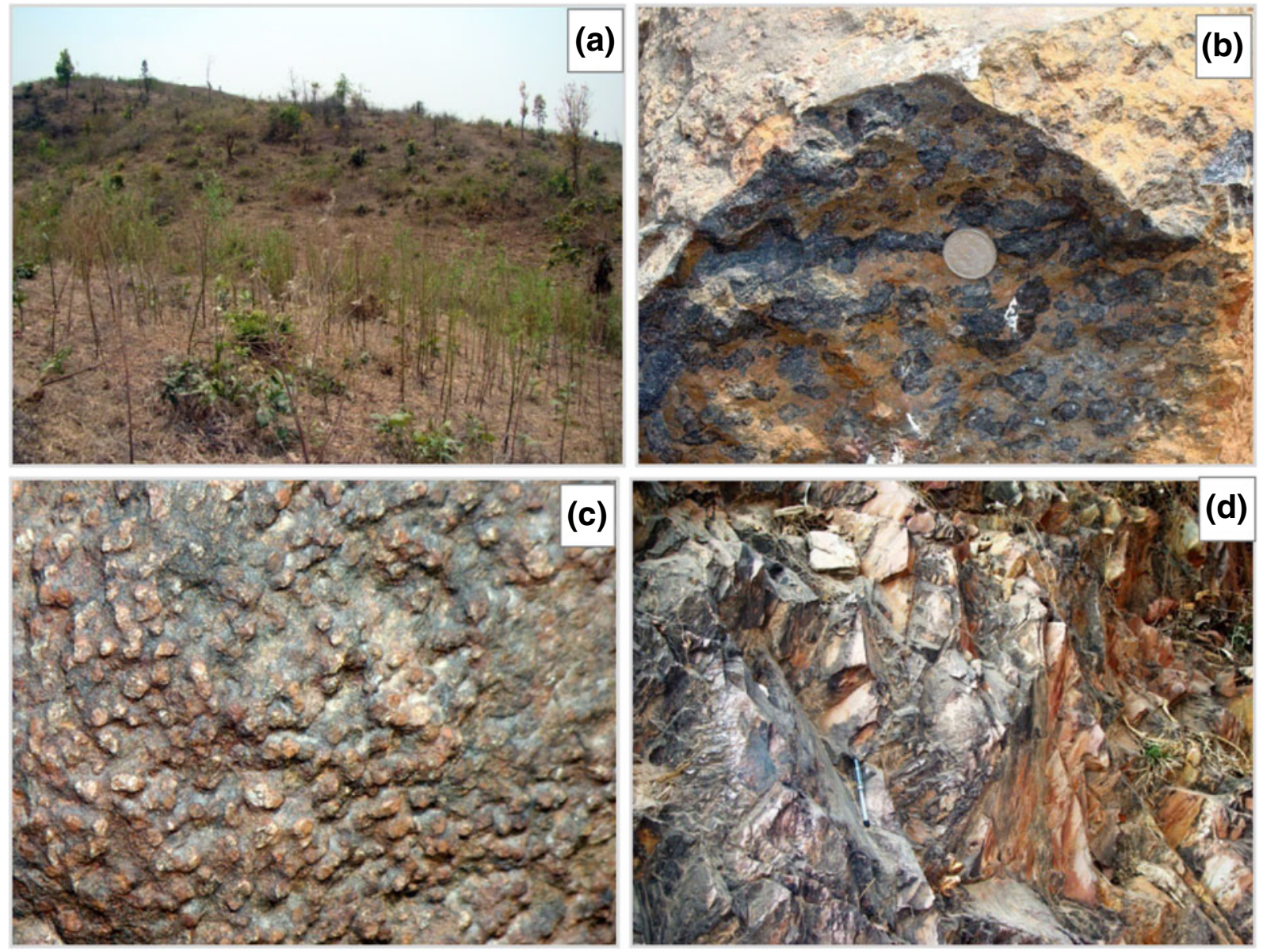

Figure 3. (a) A view of inner and middle aureoles developed near Jhirgadandi village. The granite is light colour while the dark shade represents the middle aureole, (b) the garnet and cordierite showing the hornfelsic texture in the inner zone of aureole near Nigai village, (c) garnet, cordierite and sillimanite bearing hornfelsic rock developed in the immediate vicinity of Jhirgadandi granitoid. The grains of garnet are embedded in the matrix and (d) chlorite-muscovite-biotite bearing thermal metamorphic rock from the outer to middle part of aureole, exposed at the south of Nigai village. 

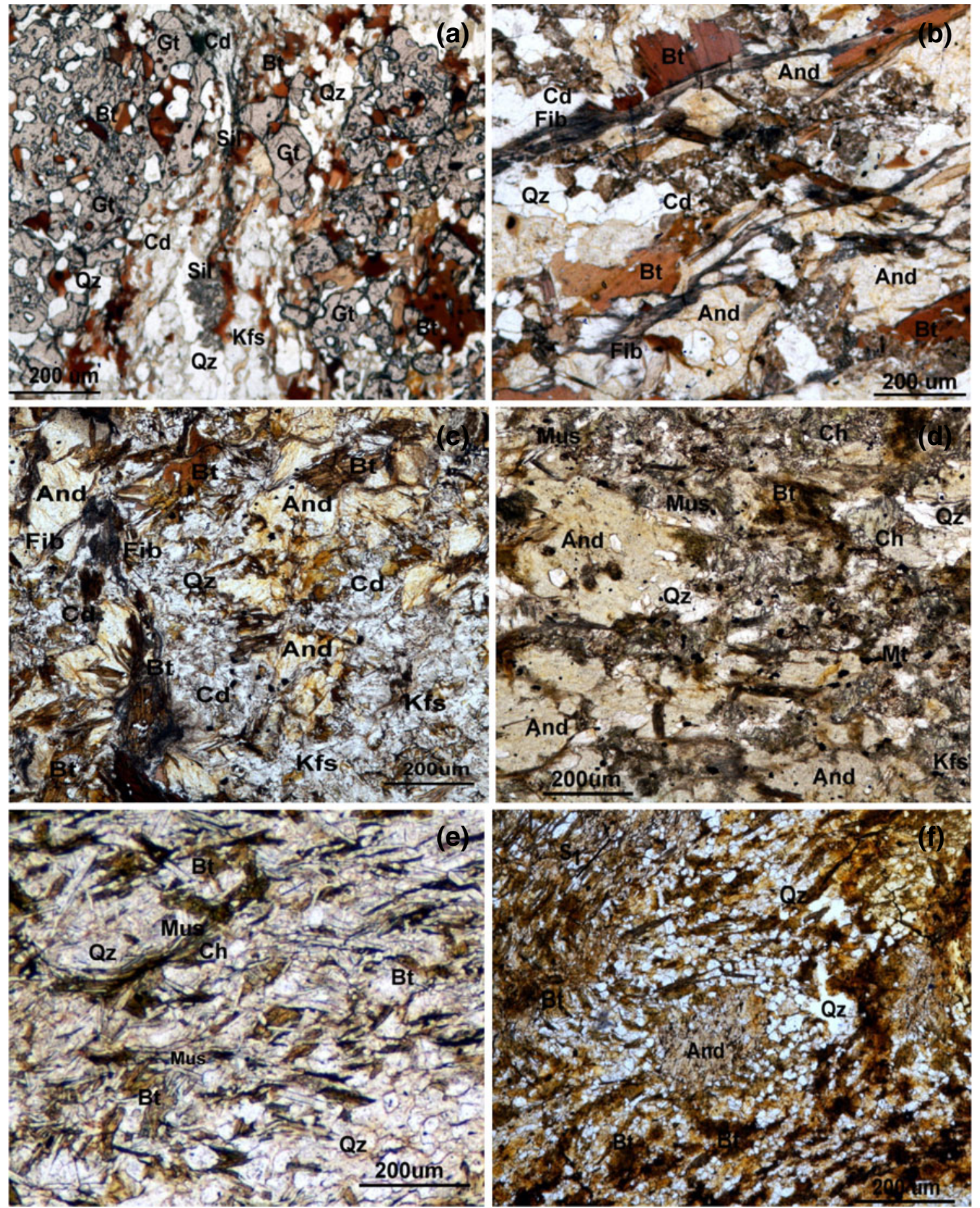

Figure 4. Photomicrograph of the contact metamorphic rocks of the inner, middle and outer aureoles: (a) Sieved garnet (Gt) with quartz and biotite association with cordierite and fibrolite in the matrix of quartz and feldspar from the inner aureole, (b) the coarse grained scarlet brown colour biotite (Bt) associated with coarse grained cordierite (Cd) and andalusite (And) in the inner aureole. Development of fibrolite (Fib) at the rim part of andalusite is also present. Bunches of fibrolite (Fib) with xenoblastic muscovite represents the dehydration reaction and decomposition textures, (c) coarse grained cordierite $(\mathrm{Cd})$ and andalusite (And) associated with scarlet biotite (Bt) from the outer part of inner aureole showing hornfelsic texture. The fibrolite (Fib) is mainly due to decomposition of muscovite (Mus), (d) coarse grained andalusite (And) from middle aureole associated with chlorite (Chl), muscovite (Mus) and biotite (Bt) in the matrix of quartz (Qz) and feldspars (Kfs) from the middle aureole, (e) overprinted texture marked by the development of muscovite and biotite in the matrix of regionally metamorphosed metapelites and (f) development of the andalusite, biotite and muscovite in the pelitic rock of outer aureole where the foliation $S_{1}$, developed during the regional metamorphism is also shown. Bar represents the magnification. Abbreviations: $\mathrm{Gt}=$ garnet, Mus=muscovite, $\mathrm{Cd}=$ cordierite, $\mathrm{Bt}=\mathrm{biotite}, \mathrm{Ksp}=\mathrm{K}-\mathrm{feldspar}$, Sil=sillimanite(fibrolite), $\mathrm{Chl}=$ chlorite, $\mathrm{q}=$ quartz and $\mathrm{Mt}=$ magnetite. 
Similarly, presence of medium to fine grained andalusite away from aureoles in the metapelites of Parsoi Formation is an indication of the influence of thermal perturbation on the larger domain as post-tectonic growth (Srivastava 1977) during the $\mathrm{M}_{2}$ event in the low grade metamorphosed terrain of Parsoi Formation of eastern part (figure 2a).

\subsection{Rocks in the contact aureole}

The progressive thermal metamorphism of the metapelites with pre-exiting foliation resulted in a steady decrease of fissility as the grade progresses (figure 3b and d). The Jhirgadandi aureole constitutes three distinct zones of aureoles, each characterized by specific mineral assemblages and textural and structural characteristics (figure 2, Srivastava 1969; Kumar 2005). The inner aureole with immediate contact with granite is characterised by high temperature minerals such as fibrolite, cordierite and garnet. The transition to the middle aureole, biotite and andalusite exhibit random orientation and decussate texture and the outer aureole have medium to fine grained metasedimentaries with shimmer texture.

\subsubsection{Inner aureole (Sil/Fibr-Bt-Crd-Grt zone)}

The inner aureole is between 25 and $50 \mathrm{~m}$ in width and lies in the immediate neighbourhood of Jhirgadandi pluton. At the immediate contact the mineralogical changes become too frequent and within a short distance the rock show dominance of garnet and fibrolite and are characterized by hornfelsic texture (figure $3 \mathrm{~b}$ and c). Cordierite and red coloured biotite are the important minerals present. The muscovite is nearly absent and decomposed into fibrolite which demarcates the beginning of this zone. Sometimes the appearance of fibrolite is marked by the phase transformation of andalusite in this zone. The assemblages developed in metapelites are characterized by biotite, cordierite, fibrolite, garnet, K-feldspar, plagioclase, quartz involved mineral phases and are portrayed in AFM diagram (figure 5).

\subsubsection{Middle aureole (And-Bt-Mus-Crd zone)}

The outer boundary of the middle aureole is characterized by decussate and sporadic granoblastic texture. The andalusite, muscovite and biotite are usually represented by the random orientation

Table 1. Representative electron microprobe analyses of garnet in the inner aureole of the study area along with their structural formula.

\begin{tabular}{|c|c|c|c|c|c|c|}
\hline $\mathrm{NG} / 2$ & 19 & 20 & 21 & 22 & 23 & 24 \\
\hline $\mathrm{SiO}_{2}$ & 36.78 & 36.68 & 36.86 & 36.28 & 36.76 & 36.67 \\
\hline $\mathrm{TiO}_{2}$ & 0.00 & 0.00 & 0.00 & 0.00 & 0.02 & 0.00 \\
\hline $\mathrm{Al}_{2} \mathrm{O}_{3}$ & 21.18 & 21.12 & 21.27 & 21.31 & 21.13 & 21.22 \\
\hline $\mathrm{Fe}_{2} \mathrm{O}_{3}$ & 0.72 & 1.56 & 1.85 & 1.60 & 1.82 & 1.17 \\
\hline $\mathrm{Cr}_{2} \mathrm{O}_{3}$ & 0.04 & 0.00 & 0.05 & 0.05 & 0.00 & 0.00 \\
\hline $\mathrm{FeO}$ & 38.42 & 37.01 & 37.02 & 37.07 & 36.61 & 38.08 \\
\hline $\mathrm{MnO}$ & 0.39 & 0.40 & 0.41 & 0.41 & 0.35 & 0.30 \\
\hline $\mathrm{MgO}$ & 2.09 & 2.90 & 1.95 & 3.08 & 3.01 & 2.32 \\
\hline $\mathrm{CaO}$ & 1.08 & 1.12 & 1.08 & 1.15 & 1.08 & 1.09 \\
\hline Total & 100.71 & 100.79 & 100.49 & 100.95 & 100.83 & 100.85 \\
\hline \multicolumn{7}{|l|}{ Based on 12 oxygen } \\
\hline $\mathrm{Si}$ & 2.971 & 2.948 & 2.983 & 2.916 & 2.954 & 2.955 \\
\hline $\mathrm{Al}^{\mathrm{iv}}$ & 0.029 & 0.052 & 0.017 & 0.084 & 0.046 & 0.005 \\
\hline $\mathrm{Al}^{\mathrm{vi}}$ & 1.987 & 1.949 & 1.985 & 1.935 & 1.950 & 2.001 \\
\hline $\mathrm{Ti}$ & 0 & 0 & 0 & 0 & 0.001 & 0 \\
\hline $\mathrm{Fe}^{3+}$ & 0.064 & 0.094 & 0.113 & 0.097 & 0.110 & 0.071 \\
\hline $\mathrm{Cr}$ & 0.003 & 0 & 0.003 & 0.003 & 0 & 0 \\
\hline $\mathrm{Mg}$ & 0.252 & 0.347 & 0.238 & 0.369 & 0.359 & 0.279 \\
\hline $\mathrm{Fe}^{2+}$ & 2.599 & 2.488 & 2.506 & 2.492 & 2.454 & 2.566 \\
\hline Mn & 0.026 & 0.027 & 0.028 & 0.028 & 0.024 & 0.02 \\
\hline $\mathrm{Ca}$ & 0.093 & 0.097 & 0.094 & 0.099 & 0.093 & 0.094 \\
\hline Almandine mole $\%$ & 87.5 & 84.1 & 87.4 & 83.4 & 83.7 & 86.7 \\
\hline Grossularite mole $\%$ & 3.1 & 3.2 & 3.2 & 3.3 & 3.1 & 3.2 \\
\hline Pyrope mole\% & 8.5 & 11.7 & 8.3 & 12.3 & 12.2 & 9.4 \\
\hline Spessartite mole\% & 0.9 & 0.9 & 1.0 & 1.0 & 0.8 & 0.7 \\
\hline
\end{tabular}


and chlorite is nearly absent. The andalusitemuscovite-biotite \pm cordierite-quartz is the prominent mineral assemblages in the pelitic rocks of this zone (figure 3d). The andalusite appears at the contact is associated with shimmer aggregates in the metapelites towards the peripheral parts.

\subsubsection{Outer aureole (Chl-And-Bt zone)}

The peripheral part of the aureole comprises mainly of phyllitic rocks with spotted appearance. The rocks are less fissile relative to the country rock. Chlorite, muscovite, biotite, sericite, ilmenite, albite, microcline, andalusite and tourmaline are the important minerals representing this zone. The first mineralogical changes are typified by the segregation of the clay minerals into shimmer aggregate and partial conversion of chlorite into biotite. The rocks of this stage give a spotted appearance and visual sign of diffusion activities in the form of growing up of clots of biotite and shimmers. The random orientation of tiny flaky minerals, viz., chlorite, sericite, and biotite are the characteristic of this zone. The andalusite of this zone is smaller and consists of tiny inclusion of chlorite and muscovite.

\section{Deformation}

Three discrete event of metamorphism were distinguished in the metasedimentary rocks surrounding the Jhirgadandi pluton:

- low-pressure and low-temperature regional metamorphism $\mathrm{M}_{1}$ and deformation $\mathrm{D}_{1}$ that overprinted primary sedimentary textures;

- relatively low pressure and high-temperature contact metamorphism $\mathrm{M}_{2}$, locally accompanied by deformation $\mathrm{D}_{2}$,

- low-pressure and low-temperature retrograde metamorphism $\mathrm{M}_{3}$ with local development of ductile shear zones $\mathrm{D}_{3}$. The last type is least developed and not much focused in the present text.

The earliest recognizable tectonic microstructures are visible in the outer zone of the contact aureole. The metapelite and metapsammite

Table 2. Representative electron microprobe analyses of muscovite mineral in the middle and outer aureoles of the study area along with their structural formula.

\begin{tabular}{|c|c|c|c|c|c|c|}
\hline \multirow{3}{*}{$\begin{array}{l}\text { Rock type } \\
\text { Ref. pt }\end{array}$} & \multicolumn{5}{|c|}{ Middle aureole } & \multirow{3}{*}{$\begin{array}{c}\text { Outer aureole } \\
\text { T3/C } \\
8\end{array}$} \\
\hline & \multicolumn{4}{|c|}{$\mathrm{T} 3 / \mathrm{C} 2 / 5$} & \multirow{2}{*}{$\frac{\mathrm{T} 3 / \mathrm{C} 2 / 1}{2}$} & \\
\hline & 28 & 29 & 79 & 80 & & \\
\hline $\mathrm{SiO}_{2}$ & 46.67 & 45.56 & 45.65 & 47.63 & 47.52 & 47.16 \\
\hline $\mathrm{TiO}_{2}$ & 0 & 0 & 0.17 & 2.09 & 0.04 & 0.47 \\
\hline $\mathrm{Al}_{2} \mathrm{O}_{3}$ & 34.58 & 33.85 & 36.64 & 29.52 & 36.66 & 36.83 \\
\hline $\mathrm{Cr}_{2} \mathrm{O}_{3}$ & 0 & 0 & 0.04 & 0 & 0.16 & 0 \\
\hline $\mathrm{FeO}$ & 1.03 & 0.11 & 1.05 & 3.91 & 1.00 & 1.13 \\
\hline $\mathrm{MnO}$ & 0.01 & 0.02 & 0 & 0.02 & 0 & 0.03 \\
\hline $\mathrm{MgO}$ & 0.61 & 0.77 & 0.38 & 1.98 & 0.43 & 0.50 \\
\hline $\mathrm{CaO}$ & 0 & 0.03 & 0.05 & 0 & 0 & 0.04 \\
\hline $\mathrm{Na}_{2} \mathrm{O}$ & 0.63 & 0.45 & 0.62 & 0.14 & 0.25 & 0.72 \\
\hline $\mathrm{K}_{2} \mathrm{O}$ & 8.64 & 8.61 & 9.76 & 9.69 & 9.40 & 8.87 \\
\hline Total & 92.14 & 90.38 & 94.35 & 94.98 & 95.43 & 95.81 \\
\hline \multicolumn{7}{|c|}{ Based on 22 oxygen } \\
\hline $\mathrm{Si}$ & 6.324 & 6.244 & 6.099 & 6.423 & 6.234 & 6.167 \\
\hline $\mathrm{Al}^{\mathrm{iv}}$ & 1.676 & 1.756 & 1.901 & 1.577 & 1.766 & 1.833 \\
\hline $\mathrm{Al}^{\mathrm{vi}}$ & 3.845 & 3.834 & 3.868 & 3.115 & 3.903 & 3.843 \\
\hline $\mathrm{Ti}$ & 0 & 0 & 0.017 & 0.212 & 0.040 & 0.046 \\
\hline $\mathrm{Cr}$ & 0 & 0 & 0.001 & 0 & 0.006 & 0 \\
\hline $\mathrm{Mg}$ & 0.124 & 0.160 & 0.075 & 0.398 & 0.084 & 0.097 \\
\hline $\mathrm{Fe}^{2+}$ & 0.116 & 0.130 & 0.117 & 0.441 & 0.110 & 0.124 \\
\hline $\mathrm{Mn}$ & 0.002 & 0.002 & 0 & 0.002 & 0 & 0.003 \\
\hline $\mathrm{Ca}$ & 0 & 0.005 & 0.007 & 0 & 0 & 0.005 \\
\hline $\mathrm{Na}$ & 0.164 & 0.121 & 0.161 & 0.037 & 0.064 & 0.184 \\
\hline $\mathrm{K}$ & 1.493 & 1.539 & 1.663 & 1.667 & 1.573 & 1.48 \\
\hline
\end{tabular}


contain foliation $\mathrm{S}_{1}$ defined by the orientation of chlorite and muscovite flakes. The green schist samples from the outcrop near Sarpatwa and south of Parach villages out side the aureole exhibits older folded foliation $\left(\mathrm{S}_{1}\right)$ defined by the syntectonic mineral assemblage actinolite + albite + epidote \pm quartz \pm chlorite in the mafic rocks and sericite \pm biotite-chlorite \pm epidote-microcline \pm albite-quartz in the pelitic rocks.

Metapelite is the most abundant thermally metamorphosed rock type in the contact aureole which is characterized by the development of cordierite, andalusite, garnet, fibrolite and Kfeldspar to andalusite, chlorite and muscovite mineral assemblages from outer to inner. The outer and middle aureoles exhibit random orientation of biotite and andalusite showing decussated texture whereas the inner zone in the immediate neighbourhood of the contact with the granite shows hornfelsic texture (figure $3 \mathrm{~b}$ and c). These textures are perhaps believed to be indicative of crystallization under the hydrostatic environment during the advanced stage of thermal metamorphism.

\section{Metamorphic evolution}

\subsection{Petrography and mineral chemistry}

The metapelitics and metapsammitic rocks involved in the thermal metamorphism around Jhirgadandi granitoid are characterized by presence of andalusite, cordierite, garnet, biotite, chlorite, quartz, plagioclase, K-feldspar, fibrolite and muscovite. Ilmenite, tourmaline, zircon, monazite and pyrite are accessory minerals. Cordierite, garnet and andalusite occur as medium to coarse porphyroblast and showing hornfelsic texture (figure 4). Porphyroblast of cordierite is associated with garnet + fibrolite (figure $4 \mathrm{a}$ ) or fibrolite + scarlet biotite (figure $4 \mathrm{~b}$ and c) in the inner aureole without any foliation and biotite + muscovite + andalusite in the middle aureole (figure 4d) with diffuse margins. Andalusite often forms large chiastolitic prismatic grains up to $30 \mathrm{~mm}$ in length, locally with small inclusions of chlorite, quartz and biotite (figure $4 \mathrm{~d}$ ). The replacement of chlorite into biotite is demarcated in this zone. The inclusions of chlorite, biotite and muscovite in the andalusite

Table 3. Representative electron microprobe analyses of biotite mineral in the inner aureole, middle aureole and enclaves (with in granite) of the study area along with their structural formula.

\begin{tabular}{|c|c|c|c|c|c|c|c|c|c|}
\hline \multirow{3}{*}{$\begin{array}{l}\text { Sample } \\
\text { Ref. pt }\end{array}$} & \multirow{2}{*}{\multicolumn{2}{|c|}{$\begin{array}{c}\text { Middle } \\
\text { T3/C2/1 }\end{array}$}} & \multirow{2}{*}{\multicolumn{2}{|c|}{$\begin{array}{l}\text { Inner } \\
\mathrm{NG} / 2 \\
\end{array}$}} & \multicolumn{5}{|c|}{ Enclave } \\
\hline & & & & & \multicolumn{5}{|c|}{ JH/ME1 } \\
\hline & 3 & 4 & 25 & 26 & 18 & 19 & 20 & 23 & 24 \\
\hline $\mathrm{SiO}_{2}$ & 39.23 & 41.77 & 34.30 & 34.44 & 37.06 & 37.48 & 36.17 & 37.08 & 36.64 \\
\hline $\mathrm{TiO}_{2}$ & 1.98 & 2.47 & 2.90 & 3.50 & 1.98 & 1.89 & 1.88 & 3.05 & 3.38 \\
\hline $\mathrm{Al}_{2} \mathrm{O}_{3}$ & 23.43 & 29.33 & 18.34 & 19.66 & 14.22 & 14.17 & 14.17 & 13.96 & 13.98 \\
\hline $\mathrm{Cr}_{2} \mathrm{O}_{3}$ & 0.08 & 0.03 & 0.14 & 0.13 & 0.07 & 0 & 0.19 & 0 & 0.01 \\
\hline $\mathrm{FeO}$ & 18.08 & 7.22 & 23.39 & 23.29 & 18.53 & 17.28 & 18.07 & 17.92 & 18.77 \\
\hline $\mathrm{MnO}$ & 0 & 0.01 & 0 & 0 & 0.38 & 0.34 & 0.31 & 0.29 & 0.30 \\
\hline $\mathrm{MgO}$ & 5.23 & 1.94 & 7.60 & 6.55 & 13.04 & 13.10 & 13.01 & 12.48 & 11.85 \\
\hline $\mathrm{CaO}$ & 0.19 & 0.05 & 0 & 0 & 0.05 & 0.12 & 0.10 & 0.05 & 0 \\
\hline $\mathrm{Na}_{2} \mathrm{O}$ & 0.12 & 0.23 & 0.11 & 0.12 & 0.13 & 0.13 & 0.10 & 0.12 & 0.09 \\
\hline $\mathrm{K}_{2} \mathrm{O}$ & 5.59 & 7.74 & 8.45 & 7.42 & 8.60 & 8.91 & 8.47 & 9.10 & 9.15 \\
\hline Total & 93.98 & 90.80 & 95.23 & 95.15 & 94.05 & 93.39 & 92.40 & 94.04 & 94.16 \\
\hline \multicolumn{10}{|c|}{ Based on 22 oxygen } \\
\hline $\mathrm{Si}$ & 5.766 & 5.996 & 5.321 & 5.296 & 5.695 & 5.765 & 5.695 & 5.696 & 5.653 \\
\hline $\mathrm{Al}^{\mathrm{iv}}$ & 2.234 & 2.004 & 2.679 & 2.704 & 2.305 & 2.235 & 2.341 & 2.304 & 2.347 \\
\hline $\mathrm{Al}^{\mathrm{vi}}$ & 1.824 & 2.958 & 0.674 & 0.859 & 0.270 & 0.334 & 0.268 & 0.222 & 0.194 \\
\hline $\mathrm{Ti}$ & 0.219 & 0.266 & 0.338 & 0.401 & 0.288 & 0.218 & 0.221 & 0.352 & 0.392 \\
\hline $\mathrm{Cr}$ & 0.003 & 0.001 & 0.006 & 0.005 & 0.003 & 0 & 0.008 & 0 & 0 \\
\hline $\mathrm{Mg}$ & 1.145 & 0.415 & 1.757 & 1.502 & 2.986 & 3.002 & 3.033 & 2.858 & 2.725 \\
\hline $\mathrm{Fe}^{2+}$ & 2.220 & 0.866 & 3.035 & 2.996 & 2.381 & 2.222 & 2.363 & 2.302 & 2.421 \\
\hline $\mathrm{Mn}$ & 0 & 0.002 & 0 & 0 & 0.049 & 0.045 & 0.041 & 0.038 & 0 \\
\hline $\mathrm{Ca}$ & 0.030 & 0.008 & 0 & 0 & 0.008 & 0.020 & 0.016 & 0.008 & 0 \\
\hline $\mathrm{Na}$ & 0.034 & 0.064 & 0.034 & 0.041 & 0.390 & 0.038 & 0.031 & 0.035 & 0.027 \\
\hline K & 1.048 & 1.418 & 1.673 & 1.445 & 1.685 & 1.745 & 1.69 & 1.783 & 1.800 \\
\hline $\mathrm{X}_{\mathrm{Mg}}$ & 0.340 & 0.324 & 0.367 & 0.334 & 0.556 & 0.575 & 0.562 & 0.554 & 0.529 \\
\hline
\end{tabular}


and their cross cutting relationship with matrix foliation in metapelites indicate overprinting due to post-tectonic thermal perturbation event.

The easily recognizable tectonic microstructures are visible in the outer zone of the contact aureole in the form of regional foliation of $\mathrm{S}_{1}$ defined by the orientation of chlorite and muscovite flakes. The green schist rocks from the outcrop near Sarpatwa and south of Parach villages (outside the aureole, figure $2 \mathrm{~b}$ ) exhibit regional metamorphic foliation $\left(\mathrm{S}_{1}\right)$ defined by the syn-tectonic mineral assemblage actinolite + albite + epidote \pm quartz \pm chlorite in the mafic rocks and sericite \pm biotite - chlorite \pm epidote - microcline \pm albite-quartz in the pelitic rocks. The regional metamorphic foliation $\left(\mathrm{S}_{1}\right)$ and overprinting of thermal texture represented by development of coarse grained andalusite and biotite minerals (figure $4 \mathrm{e}$ and $\mathrm{f}$ ) has been demarcated the beginning of outer zone of thermal metamorphism.

The mineral chemistry of the coexisting mineral phases has been discussed on the basis of representative EPMA data (tables 1-6). The electron probe analyses were carried out at Geological Survey of India (GSI) laboratory in Faridabad

Table 4. Representative electron microprobe analyses of cordierite in the inner aureole of the study area along with their structural formula.

\begin{tabular}{|c|c|c|c|}
\hline \multirow[b]{2}{*}{ Sample } & \multicolumn{3}{|c|}{$\mathrm{NG} / 2$} \\
\hline & 27 & 28 & 31 \\
\hline $\mathrm{SiO}_{2}$ & 48.32 & 48.10 & 48.40 \\
\hline $\mathrm{TiO}_{2}$ & 0.06 & 0 & 0 \\
\hline $\mathrm{Al}_{2} \mathrm{O}_{3}$ & 33.24 & 33.25 & 33.29 \\
\hline $\mathrm{Fe}_{2} \mathrm{O}_{3}$ & 0 & 0 & 0 \\
\hline $\mathrm{Cr}_{2} \mathrm{O}_{3}$ & 0.02 & 0.06 & 0.06 \\
\hline $\mathrm{FeO}$ & 11.43 & 11.44 & 11.64 \\
\hline $\mathrm{MnO}$ & 0.15 & 0.15 & 0.03 \\
\hline $\mathrm{MgO}$ & 6.23 & 6.50 & 6.28 \\
\hline $\mathrm{CaO}$ & 0.04 & 0.05 & 0 \\
\hline $\mathrm{Na}_{2} \mathrm{O}$ & 0.12 & 0.12 & 0.17 \\
\hline $\mathrm{K}_{2} \mathrm{O}$ & 0.02 & 0.07 & 0.09 \\
\hline Total & 99.54 & 99.64 & 99.98 \\
\hline \multicolumn{4}{|c|}{ Based on 18 oxygen } \\
\hline $\mathrm{Si}$ & 4.976 & 4.960 & 4.976 \\
\hline $\mathrm{Al}$ & 4.042 & 4.041 & 4.034 \\
\hline $\mathrm{Ti}$ & 0.004 & 0 & 0 \\
\hline $\mathrm{Fe}^{2+}$ & 0.986 & 0.986 & 1.001 \\
\hline $\mathrm{Cr}$ & 0.001 & 0.005 & 0.005 \\
\hline $\mathrm{Mg}$ & 0.958 & 0.998 & 0.962 \\
\hline Mn & 0.013 & 0.005 & 0.003 \\
\hline $\mathrm{Ca}$ & 0.005 & 0.005 & 0 \\
\hline $\mathrm{Na}$ & 0.025 & 0.023 & 0.034 \\
\hline $\mathrm{K}$ & 0.002 & 0.009 & 0.012 \\
\hline $\mathrm{X}_{\mathrm{Mg}}$ & 0.493 & 0.503 & 0.490 \\
\hline
\end{tabular}

(New Delhi) by CAMECA SX100 electron microprobe. Selected thin sections of approximately $40 \mu \mathrm{m}$ coated with carbon were used as targets. For silicate analysis the accelerating voltage was $15 \mathrm{kV}$ with beam current of $10 \mathrm{nA}$ and beam diameter of $1 \mu$. The standards used for different elements were $\mathrm{Al}\left(\mathrm{Al}_{2} \mathrm{O}_{3}\right)$, $\mathrm{Si}, \mathrm{Ca}\left(\mathrm{CaSiO}_{3}\right)$, Ti $\left(\mathrm{TiO}_{2}\right), \mathrm{Cr}(\mathrm{Cr}), \mathrm{Zn}(\mathrm{Zn}), \mathrm{Na}$ (albite), $\mathrm{K}$ (orthoclase), $\mathrm{Fe}\left(\mathrm{Fe}_{2} \mathrm{O}_{3}\right), \mathrm{Mn}$ (Rhodonite), $\mathrm{Mg}$ (peridote), $\mathrm{Ba}\left(\mathrm{BaSO}_{4}\right), \mathrm{F}(\mathrm{CaF} 2), \mathrm{Na}(\mathrm{NaCl}), \mathrm{P}$ (apatite). The mineral chemistry of the phases is given below:

\subsubsection{Garnet}

The chemical composition of garnet shows comparatively higher in almandine mole $\%$ which varies from $83.40 \%$ to $87.50 \%$ (table 1). The pyrope mole\% (8.30-12.30\%) and grossularite mole\% $(3.10-3.30 \%)$ of garnet is low.

\subsubsection{Muscovite}

The muscovite is recorded from all the zones of aureole. The chemical composition is more are less uniform. The $\mathrm{Al}_{2} \mathrm{O}_{3}$ composition ranges from 29.52 to $36.82 \mathrm{wt} \%$ and comparatively higher in the outer aureole (table 2). The $\mathrm{MgO}$ and $\mathrm{Cr}_{2} \mathrm{O}_{3}$ are very low usually less than $1 \mathrm{wt} \%$. The $\sum \mathrm{X}$ is higher $(1.82-1.66)$ in the middle aureoles and low $(<1.6)$ in outer aureole. Similarly the $\mathrm{Al}^{\mathrm{VI}}$ composition range from 3.8 to 3.1 p.f.u. in the middle and more than 3.8 p.f.u. in the outer aureole.

\subsubsection{Biotite}

It has variable Ti-content ranging from 2.9 to $3.5 \mathrm{wt} \%$ in the inner aureole, and 1.98 to $2.47 \mathrm{wt} \%$ in the middle aureole. Their $\mathrm{X}_{\mathrm{Mg}}$ composition range is between 0.33 and 0.37 in the inner aureole, and 0.32 to 0.34 in middle aureole. The Ticontent of biotite shows a systematic increase from lower to higher temperature from outer to inner aureole (table 3). Alkalies deficiency $(\mathrm{X}<2.0)$ is present in the biotite. The deficiency is very high in inner aureole $\left(\sum \mathrm{X}=0.38-0.03\right)$ and low in middle $\left(\sum \mathrm{X}=1.20-1.5\right)$ aureole. The $\mathrm{Al}_{2} \mathrm{O}_{3}$ composition ranges from 18 to $19 \mathrm{wt} \%$ in inner aureole, 23 to $29 \mathrm{wt} \%$ for middle. Similarly the $\mathrm{Al}^{\mathrm{IV}}$ composition ranges from 2.68 to 2.70 p.f.u. and 2.0 to 2.23 p.f.u. for inner and middle aureoles, respectively.

\subsubsection{Cordierite}

The cordierite contains mainly $\mathrm{SiO}_{2}, \mathrm{Al}_{2} \mathrm{O}_{3}, \mathrm{FeO}$, and $\mathrm{MgO}$. The $\mathrm{Na}_{2} \mathrm{O}+\mathrm{K}_{2} \mathrm{O}$ present less than $1 \%$. The $\mathrm{X}_{\mathrm{Mg}}$ of cordierite ranges from 0.49 to 0.50 
Table 5. Representative electron microprobe analyses of feldspar in the inner aureole, granite and enclaves (with in granite) of the study area along with their structural formula.

\begin{tabular}{|c|c|c|c|c|c|c|c|c|}
\hline \multicolumn{6}{|c|}{ Plagioclase } & \multicolumn{3}{|c|}{ Orthoclase } \\
\hline Rock & \multicolumn{2}{|c|}{ Inner } & \multicolumn{5}{|c|}{ Granodiorite } & \multirow{3}{*}{$\begin{array}{l}\text { Enclave } \\
\text { JH/ME1 }\end{array}$} \\
\hline Sample & \multicolumn{2}{|c|}{$\mathrm{NG} / 2$} & \multicolumn{5}{|c|}{$\mathrm{JH} / 1$} & \\
\hline Ref. pt & 32 & 33 & 13 & 17 & 21 & & & \\
\hline $\mathrm{SiO}_{2}$ & 59.83 & 60.36 & 67.58 & 65.61 & 62.79 & 64.74 & 63.36 & 64.59 \\
\hline $\mathrm{TiO}_{2}$ & 0 & 0 & 0.05 & 0 & 0.03 & 0 & 0.06 & 0.01 \\
\hline $\mathrm{Al}_{2} \mathrm{O}_{3}$ & 25.83 & 25.66 & 19.83 & 21.44 & 23.16 & 18.65 & 18.85 & 18.86 \\
\hline $\mathrm{Fe}_{2} \mathrm{O}_{3}$ & 0.05 & 0.15 & 0.07 & 0.36 & 0.02 & 0.06 & 0.011 & 0.14 \\
\hline $\mathrm{MgO}$ & 0 & 0 & 0.01 & 0.12 & 0 & 0 & 0 & 0.02 \\
\hline $\mathrm{CaO}$ & 6.72 & 6.65 & 0.02 & 1.95 & 4.00 & 0 & 0 & 0.05 \\
\hline $\mathrm{Na}_{2} \mathrm{O}$ & 7.78 & 8.02 & 11.66 & 9.75 & 9.32 & 0.41 & 0.26 & 1.20 \\
\hline $\mathrm{K}_{2} \mathrm{O}$ & 0.10 & 0.11 & 0.16 & 0.09 & 0.10 & 15.34 & 15.66 & 14.21 \\
\hline Total & 100.38 & 100.73 & 99.54 & 99.31 & 99.65 & 99.20 & 98.23 & 99.07 \\
\hline \multicolumn{9}{|c|}{ Based on 8 oxygen } \\
\hline $\mathrm{Si}$ & 2.656 & 2.665 & 2.971 & 2.895 & 2.787 & 2.99 & 2.975 & 2.987 \\
\hline $\mathrm{Al}$ & 1.351 & 1.338 & 1.027 & 1.115 & 1.212 & 1.018 & 1.043 & 1.028 \\
\hline $\mathrm{Ti}$ & 0 & 0 & 0.002 & 0 & 0.001 & 0 & 0.002 & 0 \\
\hline $\mathrm{Fe}^{3+}$ & 0.002 & 0.005 & 0.002 & 0.012 & 0.008 & 0.002 & 0 & 0.005 \\
\hline $\mathrm{Mg}$ & 0 & 0 & 0.001 & 0.008 & 0 & 0 & 0 & 0.001 \\
\hline $\mathrm{Na}$ & 0.670 & 0.680 & 0.993 & 0.834 & 0.802 & 0.037 & 0.023 & 0.108 \\
\hline $\mathrm{Ca}$ & 0.32 & 0.312 & 0.009 & 0.092 & 0.19 & 0 & 0 & 0.003 \\
\hline $\mathrm{K}$ & 0.006 & 0.006 & 0.009 & 0.005 & 0.006 & 0.906 & 0.938 & 0.838 \\
\hline $\mathrm{X}_{\mathrm{an}}$ & 0.321 & 0.313 & 0.009 & 0.099 & 0.190 & & & \\
\hline
\end{tabular}

(table 4) which indicates presence of $\mathrm{FeO}$ enriched phase component with respect to $\mathrm{Mg}$ end member cordierite.

\subsubsection{Plagioclase}

In the granitoids of Jhirgadandi, the chemical composition of plagioclase is quite constant (table 5). The anorthite ranges from $\mathrm{An}_{1}$ to $\mathrm{An}_{19}$ in the granodiorite. The higher anorthite content $\left(\mathrm{An}_{31}-\mathrm{An}_{32}\right)$ is found in the inner aureoles.

\subsubsection{Amphibole}

The calcic amphibole is present in granitoid rocks with compositional ranges from 4 to 5 wt $\%$ for $\mathrm{Al}_{2} \mathrm{O}_{3}$ (table 6). The $\mathrm{Na}_{2} \mathrm{O}$ and $\mathrm{FeO}$ are always more than 0.7 wt $\%$ and 9 wt $\%$. The $\mathrm{X}_{\mathrm{Mg}}$ ranges from 0.35 to 0.24 .

\subsection{Phase relationship and metamorphic reactions}

The granitoid pluton causes a high geothermal gradient resulted into the textural and mineralogical changes in a narrow zone. The mineral assemblages of low pressure and low to high temperature conditions from outer to inner aureole along with textural and mineralogical changes (figure 4) indicate the overprinting of contact metamorphic assemblages in the low grade regional metamorphism. Possible cordierite-producing reactions for metapelites include Mus + Chl + Qtz = $\mathrm{Crd}+\mathrm{Bt}+\mathrm{H}_{2} \mathrm{O}$ in the middle part and Mus $+\mathrm{Bt}$ $+\mathrm{Qtz}=\mathrm{Crd}+\mathrm{Kfs}+\mathrm{H}_{2} \mathrm{O}$ towards the inner part of the contact aureoles. Andalusite/fibrolite in the inner part is considered to be a product of dehydration reactions that involve mostly the breakdown of muscovite. The beginning of the contact metamorphism in the inner aureole of Jhirgadandi is also marked by the appearance of fibrolite suggests the reaction:

$$
\text { Mus }+ \text { Qtz }=\mathrm{Kf} s+\text { fibrolite }+\mathrm{H}_{2} \mathrm{O}
$$

The occurrences of garnet and cordierite along with sillimanite/fibrolite in the inner most part of the aureole of Jhirgadandi can be explained by the reaction in the KFMASH system and is advanced stage of hornfels metamorphism (figure 5).

$$
\mathrm{Als}+\mathrm{Bt}+\mathrm{Qtz}=\mathrm{Grt}+\mathrm{Cd}+\mathrm{Kfs}+\mathrm{H}_{2} \mathrm{O}
$$

The development of fibrolite at the margins of andalusite from the inner aureole zone explains the 
Table 6. Representative electron microprobe analyses of the chlorite and amphibole minerals in the outer aureole and granite of the study area along with their structural formula.

\begin{tabular}{|c|c|c|c|}
\hline \multirow{4}{*}{$\begin{array}{l}\text { Sample } \\
\text { Ref. pt }\end{array}$} & \multirow{2}{*}{\multicolumn{2}{|c|}{$\begin{array}{c}\text { Amphibole } \\
\text { Granitoid } \\
\end{array}$}} & Chlorite \\
\hline & & & Outer aureole \\
\hline & \multicolumn{2}{|c|}{$\mathrm{JH} / 2$} & $\mathrm{~T} 3 / \mathrm{C} 2 / 1$ \\
\hline & 4 & 11 & 32 \\
\hline $\mathrm{SiO}_{2}$ & 51.00 & 51.97 & 23.19 \\
\hline $\mathrm{TiO}_{2}$ & 0.17 & 0.10 & 3.55 \\
\hline $\mathrm{Al}_{2} \mathrm{O}_{3}$ & 4.11 & 3.29 & 17.06 \\
\hline $\mathrm{Fe}_{2} \mathrm{O}_{3}$ & 4.01 & 3.51 & 0 \\
\hline $\mathrm{FeO}$ & 10.45 & 9.52 & 25.46 \\
\hline $\mathrm{MnO}$ & 0.43 & 0.54 & 0 \\
\hline $\mathrm{MgO}$ & 14.49 & 15.54 & 4.50 \\
\hline $\mathrm{CaO}$ & 12.12 & 12.46 & 0.15 \\
\hline $\mathrm{Na}_{2} \mathrm{O}$ & 0.796 & 0.56 & 0.08 \\
\hline $\mathrm{K}_{2} \mathrm{O}$ & 0.35 & 0.14 & 2.50 \\
\hline Total & 97.93 & 97.54 & 76.49 \\
\hline Based on & \multicolumn{2}{|c|}{23 oxygen } & 28 oxygen \\
\hline $\mathrm{Si}$ & 7.394 & 7.501 & 5.813 \\
\hline $\mathrm{Al}^{\mathrm{iv}}$ & 0.606 & 0.499 & 2.187 \\
\hline $\mathrm{Al}^{\mathrm{vi}}$ & 0.095 & 0.061 & 2.853 \\
\hline $\mathrm{Ti}$ & 0.018 & 0.011 & 0.669 \\
\hline $\mathrm{Fe}^{3+}$ & 0.425 & 0.372 & 0 \\
\hline $\mathrm{Mg}$ & 3.130 & 3.343 & 1.680 \\
\hline $\mathrm{Fe}^{2+}$ & 1.279 & 1.158 & 5.338 \\
\hline $\mathrm{Mn}$ & 0.053 & 0.044 & 0 \\
\hline $\mathrm{Ca}$ & 1.882 & 1.926 & 0.040 \\
\hline $\mathrm{Na}$ & 0.285 & 0.181 & 0.037 \\
\hline $\mathrm{K}$ & 0.064 & 0.026 & 0.798 \\
\hline $\mathrm{X}_{\mathrm{Mg}}$ & 0.710 & 0.743 & 0.239 \\
\hline
\end{tabular}

phase transformation of aluminosilicate mineral at lower pressure.

$$
\text { And }=\text { Fibrolite }
$$

The occurrence of $\mathrm{Cd}+\mathrm{And}+\mathrm{Mus}+\mathrm{Bt}$ and $\mathrm{Cd}+\mathrm{And}+\mathrm{Bt}+\mathrm{Kfs} \pm \mathrm{Mus}$ assemblages are thus interpreted as a prograde sequence of the KFMASH model reactions which consume muscovite and generating cordierite, andalusite and Kfeldspar at low pressure. Cordierite porphyroblasts contain inclusions of muscovite and chlorite, which indicate formation of cordierite by the reaction:

$$
\mathrm{Mus}+\mathrm{Chl}+\mathrm{Qtz}=\mathrm{Cd}+\mathrm{Bt}+\mathrm{H}_{2} \mathrm{O}
$$

Andalusite locally includes biotite, muscovite and quartz grains from the matrix. These textures are consistent with prograde andalusite growth. The development of coarse grained andalusite and the presence of $\mathrm{Cd}+\mathrm{Bt}+\mathrm{Mus}+\mathrm{Als}+\mathrm{Qtz}$ in the pelitic rocks of the middle aureole of Jhirgadandi can be defined by the following reaction in the KFMASH system (Pattison et al. 2002):

$$
\mathrm{Mus}+\mathrm{Cd}=\mathrm{And}+\mathrm{Bt}+\mathrm{Qtz}+\mathrm{H}_{2} \mathrm{O}
$$

The beginning of the outer aureole of contact metamorphism in the Jhirgadandi is marked by the presence of decussate andalusite in the assemblage $\mathrm{Bt}+\mathrm{Mus}+\mathrm{And} \pm \mathrm{Chl} \pm \mathrm{Kfs}$ (microcline). The appearance of andalusite due to the decomposition of Mus $+\mathrm{Chl}$ in presence of quartz can be explained by following reaction in the KFMASH system (figure 5).

$$
\mathrm{Mus}+\mathrm{Chl}=\mathrm{Bt}+\mathrm{And}+\mathrm{Qtz}+\mathrm{H}_{2} \mathrm{O}
$$

\section{$5.3 P-T$ conditions}

The pressure and temperature conditions of metamorphism of the garnet-cordierite-fibrolitebiotite bearing hornfels of inner aureole have been estimated by conventional $\mathrm{Fe}-\mathrm{Mg}$ garnetcordierite and garnet-biotite geothermometers and garnet-biotite-K-feldspar-quartz and garnet-micaplagioclase-quartz geobarometers. Additional sets of independent reactions between mineral endmembers were calculated by THERMOCALC v3.1 using the internally consistent dataset of Holland and Powell (1998) and the internally consistent geothemobarometers of Dwivedi et al. (1997) and the results are given in table 7 . The temperature obtained from garnet-cordieritefibrolite-biotite hornfels (inner zone) estimates ranges between $650^{\circ}$ and $685^{\circ} \mathrm{C}$ for Grt-Cd and garnet-biotite geothermometry with the exceptionally some higher estimates of $698^{\circ}-721^{\circ} \mathrm{C}$ by some geothermometer (see table 7, Ferry and Spear 1978; Dwivedi 1996; Dwivedi et al. 1998) and low estimates of temperature $636^{\circ}-529^{\circ} \mathrm{C}$ (Dasgupta et al. 1991; Nichols et al. 1992). The average temperature from $\mathrm{Ti}$ content in mica geothermometer proposed by Lal (1991) estimates $661 \pm 20^{\circ} \mathrm{C}$ (inner aureole) to $580 \pm 15^{\circ} \mathrm{C}$ (middle aureole) and $487 \pm 30^{\circ} \mathrm{C}$ (outer aureole). The pressure calculated for garnet-cordierite-fibrolite hornfels using garnet-cordierite-sillimanite-quartz geobarometers for $\mathrm{Fe}$ and $\mathrm{Mg}$ endmember reactions, varies from 2.05 to $5.83 \mathrm{kbar}$. The pressure estimates by Thompson (1976) and Wells (1979) are higher compared to other geobarometers (table 7). The pressure estimates from garnetmica-plagioclase-quartz-geobarometers lie between 1.6 and $2.68 \mathrm{kbar}$. These conventional methods estimate low pressure, commonly below 4 kbar. The $\mathrm{P}-\mathrm{T}$ conditions of garnet-cordierite-sillimanite 


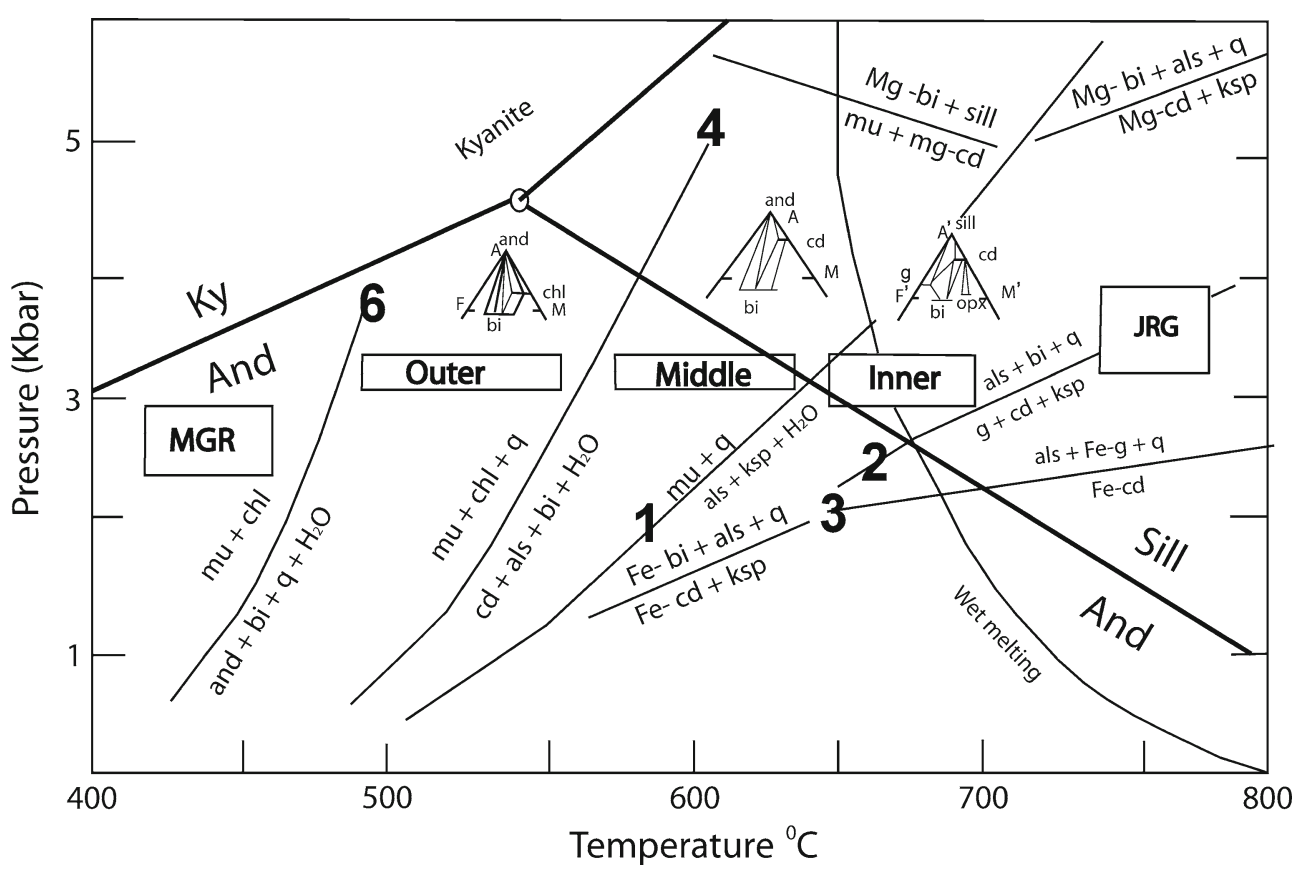

Figure 5. P-T stability field of outer, middle and inner aureoles along with the temperature of host rock (MGR) and granitoids (JGR) with different reaction curves/line to estimate the $\mathrm{P}-\mathrm{T}$ conditions of metamorphism. The curved line marked with numbers involved metamorphic reactions discussed in the phase relationship section. The boxes represent the pressure-temperature conditions estimated by geothermobaromery. The triple point (Pattison et al. 2002), univariant curve of andalusite and sillimanite and the relationship with observed reaction textures view that metamorphism at Jhirgadandi is low pressure and medium to high temperature. The AFM projections represent the observed assemblages in the concerned zone of aureole of Jhigadandi. The abbreviations are: $\mathrm{g}=$ garnet, $\mathrm{mu}=$ muscovite, als=aluminosilicates, and=andalusite, $\mathrm{cd}=$ cordierite, $\mathrm{bi}=$ biotite, $\mathrm{ksp}=\mathrm{K}$-feldspar, Liq=liquid, sill=sillimanite, $\mathrm{Pl}=$ plagioclase, q=quartz, MGR: Mahakoshal Group and JGR: Jhirgadandi granitoid.

(fibrolite) bearing rocks from the internally consistent geothermobarometers and internally consistent dataset varies from $690^{\circ} \mathrm{C} / 3.4 \mathrm{kbar}$ (Dwivedi et al. 1997) to $690^{\circ} \mathrm{C} / 4.11 \mathrm{kbar}$ (THEMOCALC v.3.1).

Based on the proposed metamorphic reactions and their stability, a $\mathrm{P}-\mathrm{T}$ phase diagram is shown in figure 5 which represents the three distinct zone of contact aureole and their wide range of temperature condition within the aureole and its surrounding. The temperature estimated from hornblende-plagioclase thermometry (Holland and Blundy 1994) has been used to characterize the emplacement conditions of the amphibole-biotite granodiorite and enclaves, provide the temperature $634 \pm 35$ to $650 \pm 25^{\circ} \mathrm{C}$ respectively. It seems that the emplacement condition of c. $634 \pm 35$ to $650 \pm$ $25^{\circ} \mathrm{C}$ is lower than the peak metamorphic condition of the garnet-bearing assemblages of the inner contact zone $\left(690^{\circ} \mathrm{C} / 3.4 \mathrm{kbar}\right)$, but this discrepancy is difficult to assess in the present uncertainty of the $\mathrm{P}-\mathrm{T}$ condition derived from THERMOCALC. We would have thought that granitic intrusion is typically emplaced at conditions of about 700 $800^{\circ} \mathrm{C}$ and the estimates of temperature reflects the cooling temperature during equilibration of mineral phases.

\section{Conclusions}

The Jhirgadandi pluton consists of amphibolebiotite granodiorite was possibly emplaced at a pressure of c. 2 kbar, equivalent to a depth of c. $7 \mathrm{~km}$ into the low grade regionally metamorphosed $\left(\mathrm{M}_{1}\right)$ Parsoi Formation of Mahakoshal Group. The contact metamorphism $\left(\mathrm{M}_{2}\right)$ at Jhirgadandi occurs as a result of a higher geothermal gradient produced locally around intruding magma. Metapelite, the most abundant rock type of the contact aureole metamorphism is characterized by the development of andalusite, chlorite and muscovite to cordierite, andalusite, garnet, fibrolite and K-feldspar mineral assemblages. Mineral assemblages delineate three metamorphic zones within the contact aureole: outer aureole (Chl-And-Bt zone), middle aureole (AndBt-Mus-Cd zone) and inner aureole (Sil/Fibr-Bt$\mathrm{Cd}-$ Grt-zone). The internally consistent geothermobarometry estimates the $690^{\circ} \mathrm{C} / 3.4$ kbar for the thermal peak of contact metamorphism in the 
Table 7. Pressure and temperature estimates of the contact aureole and surrounding granite including enclaves using conventional geothermobarometers and internally consistent dataset.

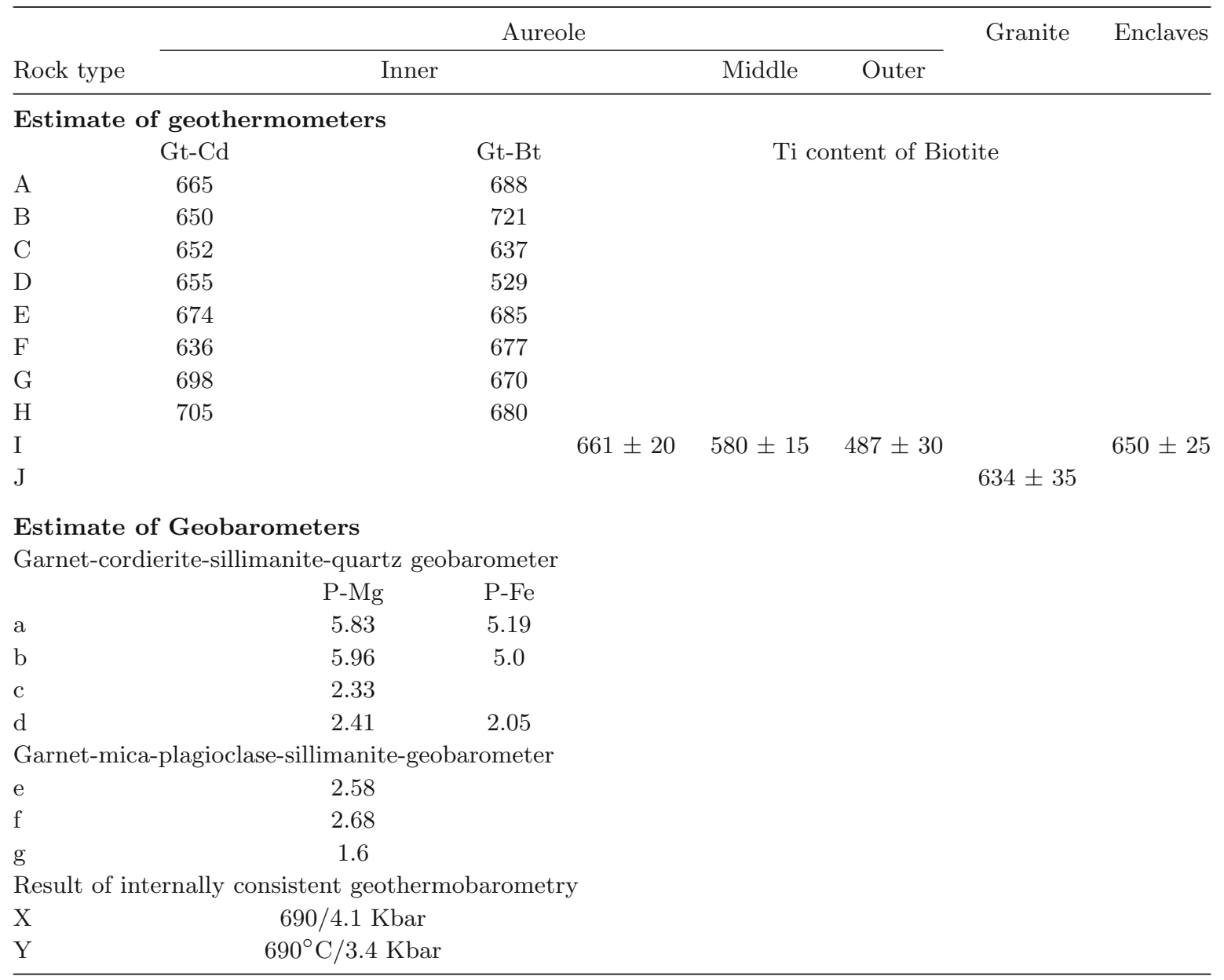

Note: In Gt-Cd, A=Thompson (1976), B=Perchuk et al. (1985), C=Bhattacharya et al. (1992b), D=Perchuk (1991), E=Aranovich and Podlesskii (1983), $\mathrm{F}=$ Nichols et al. (1992), G=Dwivedi (1996), H=Dwivedi et al. (1998); I=Lal (1991), J=Holland and Blundy (1994). In Gt-Bt, A=Thompson (1976), B=Ferry and Spear (1978), C=Perchuk et al. (1985), D=Dasgupta et al. (1991), $\mathrm{E}=$ Aranovich et al. (1988), $\mathrm{F}=$ Bhattacharya et al. (1992a), $\mathrm{G}=$ Holdaway (2000), $\mathrm{H}=$ Dwivedi et al. (2007); $\mathrm{a}=$ Thompson (1976), b=Wells (1979), c=Perchuk et al. (1985), d=Nichols et al. (1992), e=Koziol and Newton (1988), $\mathrm{f}=$ Hoisch (1990), $\mathrm{g}=\mathrm{Wu}$ et al. (2004). $\mathrm{X}=$ Thermocalc (Holland and Powell 1998), $\mathrm{Y}=$ Dwivedi et al. (1997).

inner aureole of the Jhirgadandi. The metamorphic temperatures based on different geothermometers are $487 \pm 30^{\circ} \mathrm{C}$ in the outer aureole, $580 \pm 15^{\circ} \mathrm{C}$ in the middle aureole and $661 \pm 20^{\circ} \mathrm{C}$ in the inner aureole at pressures between 1.6 and 2.58 kbar represent agreement of gradual thermal perturbation at shallow depth in the width between 600 and $800 \mathrm{mt}$ across the Jhirgadandi pluton.

\section{Acknowledgements}

AKS and GK gratefully acknowledge Shri Ravi Shanker, Director General (Retd.) GSI, Shri P L Nalrula, Dy DG (Retd), GSI, Dr N C Pant and Shri D K Bhatnagar, and Shri Hemant Kumar of GSI for providing facilities and able assistance in
EPMA analysis. Dr Ram Mohan (NGRI) Hyderabad is acknowledged for fruitful discussion and suggestions during the preparation of manuscript. The authors thank Dr S Paul for his constructive comments and suggestion to improve the manuscript.

\section{References}

Acharyya S K and Roy A 2000 Tectonothermal history of the central Indian tectonic zone and reactivation of major faults/shear zones; J. Geol. Soc. India 55 239-256.

Aranovich L Y A and Podlesskii K K 1983 Tahe cordieritegarnet-sillimanite equilibrium: Experiments and application; In: Kinetics and equilibrium in mineral reactions (ed.) Saxena S K (Berlin: Springer-Verlag), pp. 173-198. 
Aranovich L Y A, Lavrent'eva I V and Kosyakova N A 1988 Biotite-garnet and biotite-orthopyroxene geothermometers: Calibrations accounting for the $\mathrm{Al}$ variations in biotite; Geokhim. 5 668-676.

Bhattacharya A, Mazumdar A C and Sen S K 1992a Fe$\mathrm{Mg}$ mixing in cordierite: Constraints from natural data and implication for cordierite-garnet geothermometry in granulites; Am. Mineral. 73 338-344.

Bhattacharya A, Mohanty L, Maji A, Sen S K and Raith M 1992b Non-ideal mixing in the phlogopite-annite binary solution: Constraints from experimental data on $\mathrm{Mg}-\mathrm{Fe}$ partitioning and a reformulation of the biotitegarnet geothermometers; Contrib. Mineral. Petrol. 111 87-93.

Brocker M and Franz L 2000 The contact aureole on Tinos (Cyclades, Greece): Tourmaline-biotite geothermometry and Rb-Sr geochronology; J. Mineral. Petrol. 70 257-283.

Buntebarth G 1991 Thermal models of cooling; In: Equilibrium and kinetics in contact metamorphism: the Ballachulish igneous complex and its aureole (eds) Voll G, Toepel J, Pattison D R M and Seifert F (Berlin, Heidelberg, New York: Springer), pp. 379-402.

Buriánek D and Dolníček Z 2011 Metamorphic evolution of the contact aureole of the Dipilto Batholith, Eastern Chortis Terrane, Nicaragua; J. Geosci. 56 9-26.

Cartwright I and Buick I S 1996 Determining the direction of contact metamorphic fluid flow: An assessment of mineralogical and stable isotope criteria; J. Met. Geol. 14 289-305.

Das B K 1985 Petrology of thermally metamorphosed pelitic rocks in the Champawat Area, Kumaun Himalaya; J. Earth Syst. Sci. 97 57-70, doi: 10.1007/BF02834096.

Dasgupta S, Sengupta P, Guha D and Fukuoka M 1991 A refined garnet-biotite $\mathrm{Fe}-\mathrm{Mg}$ exchange geothermometer and its application in amphibolites and granulites; Contrib. Mineral. Petrol. 109 130-137.

Dwivedi S B 1996 Non-ideal Mg-Fe binary mixing in cordierite: Constraints from experimental data on $\mathrm{Mg}-\mathrm{Fe}$ partitioning in garnet and cordierite and a reformulation of garnet-cordierite geothermometer; J. Earth Syst. Sci. $105365-377$.

Dwivedi S B, Mohan A and Lal R K 1997 Internally consistent geothermobarometers in the system $\mathrm{FeO}-\mathrm{MgO}-$ $\mathrm{Al}_{2} \mathrm{O}_{3}-\mathrm{SiO}_{2}-\mathrm{H}_{2} \mathrm{O}$ involving garnet, cordierite, aluminosilicate and quartz and their application to metapelites; J. Geol. Soc. India 49 647-669.

Dwivedi S B, Mohan A and Lal R K 1998 Recalibration of the $\mathrm{Fe}-\mathrm{Mg}$ exchange reaction between garnet and cordierite as a thermometer; Eur. J. Mineral. 10 281-289.

Dwivedi S B, Lalnumawia J, Vanthangliana V and Lal S N 2007 A refined garnet-biotite thermometer: Constraints from empirically derived margules parameters for garnet $\left(\Delta \mathrm{W}_{\mathrm{Ca}} \& \Delta \mathrm{W}_{\mathrm{Mn}}\right)$ and biotite $\left(\Delta \mathrm{W}_{\mathrm{Al}} \& \Delta \mathrm{W}_{\mathrm{Ti}}\right) ;$ The Ind. Mineral. 41 97-111.

Ferry J M and Spear F S 1978 Experimental calibration of the partitioning of $\mathrm{Fe}$ and $\mathrm{Mg}$ between biotite and garnet; Contrib. Mineral. Petrol. 66 113-117.

Hanson R B 1995 The hydrodynamics of contact metamorphism; Geol. Soc. Am. Bull. 107 595-611.

Hoisch T D 1990 Empirical calibration of six geobarometers for the mineral assemblage quartz + muscovite + biotite + plagioclase + garnet; Contrib. Mineral. Petrol. $124225-234$.

Holdaway M J 2000 Application of new experimental and garnet margules data to the garnet-biotite geothermometer; Am. Mineral. 85 881-892.

Holland T J B and Blundy J D 1994 Non-ideal interactions in calcic amphiboles and their bearing on amphibole- plagioclase thermometry; Contrib. Mineral. Petrol. 116 433-447.

Holland T J B and Powell R 1998 An internally-consistent thermodynamic dataset for phases of petrological interest; J. Met. Geol. 16 309-344.

Iqballudin and Mohgni A 1981 Stratigraphy of the Bijawar Group in Son Valley, Mirzapur district and Sidhi district, M.P.; Geol. Surv. India Spec. Publ. 3 81-93.

Kerrick D M 1987 Fibrolite in contact aureoles of Donegal, Ireland; Am. Mineral. 72 240-254.

Koziol A M and Newton R C 1988 Redetermination of the anorthite break down reaction and improvement of the plagioclase-garnet- $\mathrm{Al}_{2} \mathrm{SiO}_{5}$-quartz geobarometer; Am. Mineral. 73 216-223.

Kumar G 2005 Geology of Uttar Pradesh and Uttranchal; Geol. Soc. India, Bangalore, 383p.

Kusunose Y O, Morikiyo T, Kawabata A and Uyeda A 2003 Carbon isotopic thermometry and geobarometry of sillimanite isograd in thermal aureoles: The depth of emplacement of upper crustal granitic bodies; Contrib. Mineral. Petrol. 145 534-549, doi: 10.1007/s00410-003-0479.

Lal R K 1991 Ti content of mica as a geothermobarometry; Third Indo-Soviet Symposium on Experimental Mineralogy and Petrology, New Delhi, pp. 13-15.

Mathur S M and Narain K 1981 Geosyncinal sedimentation with Archaeans of the Mirzapur-Sidhi area; Geol. Surv. India Spec. Publ. 3 31-37.

Nair K K K, Jain S C and Yedekar D B 1995 Stratigraphy, structure and geochemistry of Mahakoshal greenstone belt; Geol. Soc. India Memoir 31 403-432.

Nichols G T, Berry R F and Green D H 1992 Internally consistent granitic spinel-cordierite-garnet equilibrium in the FMASHZn system, geothermobarometry and application; Contrib. Mineral. Petrol. 111 362-373.

Norton D and Knight J 1977 Transport phenomena in hydrothermal systems: Cooling plutons; Am. J. Sci. 277 937-981.

Pande D, Sinha K K and Sharma P K 1996 Jhirgadandi pluton - a lower proterozoic, A type, anorogenic, within plate granite from Son Narmada lineaments Sonbhadra district, Uttar Pradesh; Abstr. vol., 10th Convention of Indian Geol. Congress, National seminar on Precambrian crustal evolution and metallogenesis, Dhanbad, pp. 65-66.

Pattison D R M, Spear F S, Debuhr C L, Cheney J T and Guidotti C V 2002 Thermodynamic modelling of the reaction muscovite + cordierite $\rightarrow \mathrm{Al} 2 \mathrm{SiO} 5+$ biotite + quartz $+\mathrm{H} 2 \mathrm{O}$ : Constraints from natural assemblages and implications for the metapelitic petrogenetic grid; J. Met. Geol. 20 99-118.

Perchuk L L 1991 Derivation of a thermodynamically consistent set of geothermometers and geobarometers for metamorphic and magmatic rocks; In: Progress in Metamorphic and Magmatic Petrology (A memorial volume in honor of DS Korzhinsky) (eds) Perchuk L L, Cambridge University Press, pp. 93-112.

Perchuk L L, Aranovich L Y A, Podlesskii K K and Lavrenteva I V 1985 Precambrain granulites of the Alden Shield; Eastern Siberia USSR 3 265-310.

Pognante G, Castelli D, Benna P, Genovese G, Oberli F, Mercier M and Tonarini R 1990 The crystalline units of the High Himalayas in the Lahaul-Zanskar region, northwest India: Metamorphic-tectonic history and geochronology of the collided and imbricated Indian plate; Geol. Mag. 127(2) 101-116.

Radhakrishna B P 1989 Suspect tectono-stratigraphic terrain elements in the Indian subcontinent; J. Geol. Soc. India 34 1-24. 
Ravi Shanker 1993 Structural and geomorphological evolution of 'SONATA' rift-zone in central India in response of Himalayan uplift; J. Palaeontol. Soc. India 38 17-30.

Rossetti F, Tecce F, Andrea A and Brilli M 2007 Patterns of fluid flow in the contact aureole of the Late Miocene Monte Capanne pluton (Elba Island, Italy): The role of structures and rheology; Contrib. Mineral. Petrol. 153 $743-760$.

Roy A 2008 Magma emplacement in central Indian tectonic zone - An evidence for large scale crustal growth and recycling during Proterozoic: A review; National Symposium on Geodynamics and evolution of Indian Shield through time and space (Golden Jubilee of the Geological Society of India at Centre for Earth Science Studies, Thiruvananthapuram, pp. 1-2.

Roy A and Devarajan M K 2000 Appraisal of the stratigraphy and tectonics of Proterozoic Mahakoshal Supracrustal belt, central India; Geol. Surv. India Spec. Publ. 57 79-97.

Roy A, Hanuma Prasad M and Devarajan M K 2002 Ductile shearing and synkinematic granite emplacement along the southern margin of Mahakoshal supracrustal belt: Evidence from Singrauli area, Madhya Pradesh; J. Geol. Soc. India 59 9-21.

Sarkar A, Bodas M S, Kundu H K, Mamgain V D and Ravishankar 1998 Geochronology and geochemistry of Paleoproterozoic intrusives plutonites from the eastern segments of the Mahakoshal greenstone Belt, Central India, Abstract, International Seminar on Precambrian Crust in Eastern and Central India at Bhubaneswar, pp. $81-84$.

Sita Bora and Kumar S 2012 Geochemistry and U-Pb SHRIMP Zircon chronology of granitoid and microgranular enclaves from Jhirgadandi pluton, Dudhi gneissic complex, Central India tectonic zone, India; Abstract, National Seminar on Recent advances and future challenges in geochemistry and geophysics: The Indian scenario, held at Varanasi, 120p.

Srivastava A K 1969 A petrochemical study of the Jhirgadandi aureole rocks district Mirzapur, Uttar Pradesh, India; J. Geol. Soc. India 4 82-93.

Srivastava A K 1977 On the enatectic origin of the granitic rocks of Jhirgadandi Pluton, Mirzapur district, Uttar Pradesh; Bull. Indian Geol. Assoc. 10(2) 37-44.
Srivastava A K and Kumar G 2010 Jhirgadandi Pluton: Origin of granitoid magama and its tectonic implications; An abstract at National Symp. on Geology and Mineral Resources of Bundelkhand Craton, GMRB 2010, held at Bundelkhand University, Jhansi, pp. 21-22.

Srivastava A K, Kumar H Pandey and Kumar G 2000a Geochemical characteristics of the Jhirgadandi granitoid, Sonbhadra district, Uttar Pradesh; In: Proc. National Seminar on Tectonomagamatism, Geochemistry and Metamorphism of Precambrian Terrains (eds) Gyani K C and Kataria P, University Department of Geology, Udaipur, pp. 189-199.

Srivastava A K, Kumar H, Ravi Shankar and Kumar G 2000b Observations on mafic and microgranular enclaves hosted in Jhirgadandi pluton, Sonbhadra district, Uttar Pradesh; Geosci. J. 31 139-146.

Steck A, Epard J, Vannay J C, Hunziker J, Girard M, Morard A and Robyr M 1998 Geological transect across the Tso Morari and Spiti areas: The nappe structures of the Tethys Himalaya; Eclogae Geol. Helvetiae. 91 103-121.

Symmes G and Ferry J M 1995 Metamorphism, fluid flow and partial melting in pelitic rocks from the Onawa Contact Aureole, Central Maine, USA; J. Petrol. 36 587-612.

Thakur V C 1993 Geology of the western Himalaya; Pergamon Press, Oxford, 366p.

Thompson A B 1976 Mineral reaction in pelitic rocks: I. Prediction in $\mathrm{P}-\mathrm{T}-\mathrm{X}(\mathrm{Fe}-\mathrm{Mg})$ phase relations. II. Calculations of some P-T-X (Fe-Mg) phase relations; Am. J. Sci. 276 401-454.

Vijan A R, Dutta D, Singh M P, Ghosh N, Rathore A K and Uniyal A K 2003 Imprint of Himalayan Orogeny on Pan African Granitoid Intrusives: Evidence from Dhaoladhar Granite NW Himalaya, India; In: Granitoids of the Himalayan Collisional Belt (ed.) Singh S; J. Virtual Explorer 11 28-30.

Wells P R A 1979 Chemical and thermal evolution of Archean sialic crust, southern Greenland; J. Petrol. 20 187-226.

Wu C M, Zhang Z and Ren L D 2004 Empirical garnet-biotite-plagioclase quartz (GBPQ) geobarometry in medium to high-grade metapelites; J. Petrol. 45 1907-1921. 